\title{
Plant diversity and composition at three Imperata grasslands in Bogor, Katingan, and Kupang, Indonesia
}

\author{
DIDI USMADI", JOKO RIDHO WITONO, RENI LESTARI, DIDIK WIDYATMOKO, MAHAT MAGANDHI, \\ IYAN ROBIANSYAH, ARIEF NOOR RACHMADIYANTO, DANANG WAHYU PURNOMO, \\ RIZMOON NURUL ZULKARNAEN, REZA RAMDAN RIVAI, HENDRA HELMANTO, \\ ANGGA YUDAPUTRA, FRISCA DAMAYANTI
}

Research Center for Plant Conservation and Botanic Gardens, Indonesian Institute of Sciences. J1. Ir. H. Juanda No. 13, Bogor 16122, West Java, Indonesia. Tel.: +62-251-8322187, 8321657, Fax.: +62-251-8322187, `email: didi.usmadi@gmail.com

Manuscript received: 4 March 2020. Revision accepted: 27 May 2020.

\begin{abstract}
Usmadi D, Witono JR, Lestari R, Widyatmoko D, Magandhi M, Robiansyah I, Rachmadiyanto AN, Purnomo DW, Zulkarnaen RN, Rivai RR, Helmanto H, Yudaputra A, Damayanti F. 2020. Plant diversity and composition at three Imperata grasslands in Bogor, Katingan, and Kupang, Indonesia. Biodiversitas 21: 2804-2813. Imperata grassland is among the largest proportions of marginal lands in Indonesia. Despite the dominance of Imperata cylindrica grass, certain plant species are able to compete and live together with this notorious species, suggesting window of opportunity that the grasslands can be restored. Yet, the existing diversity and composition of plants in Imperata grasslands may vary due to differences in climatic and soil conditions. This study aims to determine the plant diversity and composition at three Imperata grasslands in Bogor, Katingan, and Kupang, Indonesia. Data were collected using systematic sampling by establishing quadratic observation plots with size of each plot was $1 \mathrm{x} 1 \mathrm{~m}^{2}$. The total number of species found in Imperata grasslands in those three study sites was 81 species, belonging to 68 genera and 30 families. In the Bogor site, the dominant species were Imperata cylindrica, Ageratum conyzoides, and Phyllanthus niruri, while in the Katingan site was dominated by I. cylindrica, Scleria ciliaris, and Cyanthillium cinereum, and in the Kupang site was dominated by I. cylindrica and Tridax procumbens. The Imperata grassland in Bogor had low species richness, moderate species diversity, the abundance distribution of each species tends to be uniform, and the occurred species did not tend to dominate. The Katingan and Kupang Imperata grasslands had low species richness, low species diversity, the abundance distribution of each species tends to be uneven, and were more dominated by $I$. cylindrica. Controlling abundance of I. cylindrica is required in those three research sites in order to stimulate the growth of other plant species, which is in turn to maintain and restore biodiversity.
\end{abstract}

Keywords: Conservation, Imperata grassland, plant composition, plant ecology, species diversity

\section{INTRODUCTION}

Imperata grassland is a marginal land where the vegetation is dominated by alang-alang or cogon grass (Imperata cylindrica (L.) P. Beauv.). The grass belongs to the Poaceae family, it is widely distributed throughout the tropics and sub-tropics of Africa, Eastern Asia, China, Middle Asia, Western Asia, Indian Subcontinent, Southeast Asia, Eastern Asia, Australia, Northern and Southern America, Southeastern and Southwestern Europe, and Pacific (USDA 2020). It is considered as one of major invasive species. In 1997, Indonesia was a country with the largest area that was invaded by I. cylindrica in tropical Asia. The Indonesian area that has been invaded by $I$. cylindrica is c. 8.6 million ha or approximately $4.5 \%$ of the total land area of Indonesia with the largest distribution occurred in Kalimantan, Sumatra, and Nusa Tenggara (Garrity et al. 1997). In 2013, the area of critical land in Indonesia which had a risk to be invaded by I. cylindrica was around 24.2 million ha (Central Bureau of Statistics 2017).

Imperata grassland is the dominant land cover following deforestation (Yonekura 2009). The accelerated invasion of Imperata grass on deforested and degraded lands is mainly caused by its physiological traits, including the extensive rhizome system, high adaptation to poor soils, drought tolerance, genetic plasticity, and fire adaptability (GISD 2020). On land where burning is continuous event, I. cylindrica is often the dominant species in the area, whereas, on protected areas disturbed by degradation, the grasslands often serve as a starting point in vegetation succession that will develop into secondary forests (Yassir and Arbainsyah 2014).

The negative impacts of Imperata invasion include reducing or displacing the diversity of native plants (Brewer 2008), increasing the intensity and frequency of fires (Lippincott 2000), and changing nitrogen and phosphorus cycles (Daneshgar and Jose 2009). Although, the presence of I. cylindrica gives negative impacts to the environment, various species of plants can still coexist and grow in the Imperata grasslands.

Some previous research on Imperata grasslands in relation to plant diversity include decreased plant species diversity due to the invasion of Imperata in the USA (Brewer 2008), the species diversity of Imperata grassland in India (Astapati and Das 2012), plant species diversity at the initial succession stage in the Imperata grassland of East Kalimantan, Indonesia (Yassir and Arbainsyah 2014), 
and plant species diversity in post-fire succession in the Tegal Panjang grassland, Mount Papandayan (Sulistyawati and Fitriana 2017). The fact that certain plant species are able to compete and live together with I. cylindrica as mentioned in above studies can provide information on how the diversity and structure of native plants in the Imperata grasslands can be increased and restored.

The structure and composition of a plant community are determined by abiotic conditions, biotic factors, and disturbances (Mitchell et al. 2017). In Imperata grassland, species diversity, structure, and composition are influenced by soil properties (Yassir et al. 2010). Therefore, it is important to study the diversity and composition of plant species in Imperata grasslands in different locations that have different climatic and soil conditions. This study aimed to determine plant diversity and composition at three Imperata grasslands in Bogor (West Java), Katingan (Central Kalimantan), and Kupang (East Nusa Tenggara), which represent climate and soil differences in Indonesia. Results of the research can be used as the scientific basis of Imperata grasslands management in Indonesia.

\section{MATERIALS AND METHODS}

\section{Study period and locations}

Data were collected from March to December 2016 at three locations of Imperata grasslands based on the differences in climate and soil conditions. The research sites were as follows: (i) Imperata grassland in Bogor was located in Ecopark Cibinong, Cibinong Science Center and Botanic Gardens, Bogor District (6 $6^{0} 29^{\prime} 18^{\prime \prime}$ S, 106 $51^{\prime} 21^{\prime \prime}$ E) with an altitude of $150 \mathrm{~m}$ asl.; (ii) Katingan Botanic Gardens, Katingan District ( $1^{0} 53$ '21" S, 113027'51" E ) with an altitude of $45 \mathrm{~m} \mathrm{asl}$; and (iii) Kupang District Government Complex, Kupang District (1004'28" S, $123^{0} 51^{\prime} 57^{\prime \prime} \mathrm{E}$ ) with an altitude of $20 \mathrm{~m}$ asl. (Figure 1). The climatic and soil conditions at three research site are shown in Table 1.

\section{Data collection procedures}

Data were collected using systematic sampling by establishing quadratic observation plots. The observation plot size was $1 \times 1 \mathrm{~m}^{2}$ each with the distance between plots was $5 \mathrm{~m}$ (Figure 2). The number of observation plots at each Imperata grassland was 20 plots (i.e. $20 \mathrm{~m}^{2}$ ). Within each observation plot, all individuals of undergrowth plants and seedlings found were counted. Seedlings are the initial regeneration stage of trees with a height of less than $1.5 \mathrm{~m}$, while undergrowth is a plant that cannot grow up to tree levels, such as grass, herbs, lianas, and ferns.
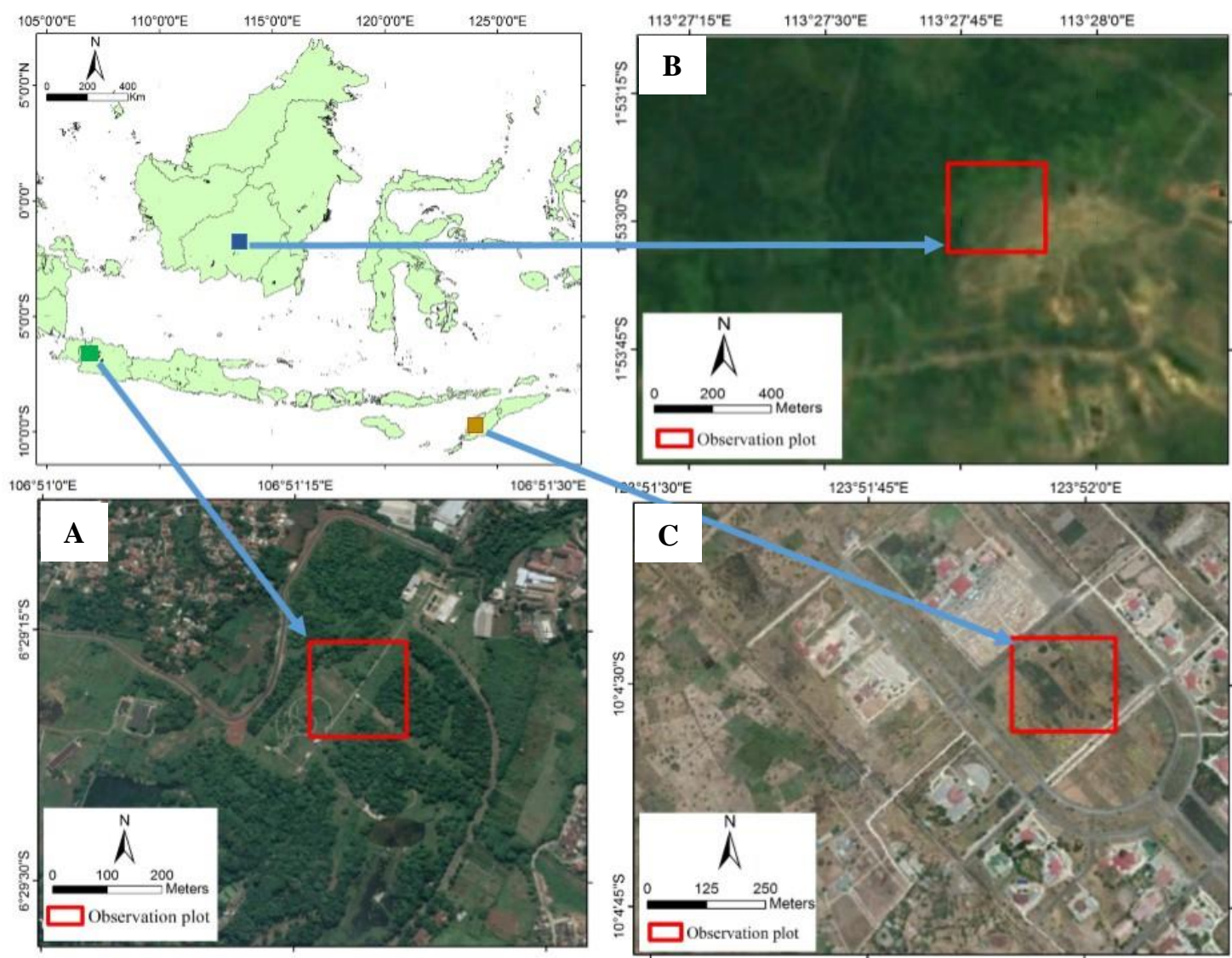

Figure 1. Imperata grassland research sites in Indonesia: A. Bogor, B. Katingan, C. Kupang (Source: Google.earth.com) 
Table 1. Climatic and soil conditions in three research sites

\begin{tabular}{llll}
\hline Condition & Bogor & Katingan & Kupang \\
\hline Climatic* & & & \\
Temperature $\left({ }^{\circ} \mathrm{C}\right)$ & $26.24 \pm 0.77$ & $27.61 \pm 1.01$ & $28.14 \pm 1.18$ \\
Humidity $(\%)$ & $84.71 \pm 3.97$ & $83.29 \pm 4.57$ & $76.50 \pm 9.48$ \\
Monthly rainfall (mm) & $387.08 \pm 125.85$ & $295.21 \pm 98.73$ & $103.31 \pm 107.53$ \\
Climate type (Schmidt-Ferguson) & A (very wet) & B (wet) & E (almost dry) \\
Soil** & & & \\
pH H H $_{\text {O }}$ & $6.36 \pm 0.23$ & $6.32 \pm 0.38$ & $8.52 \pm 0.09$ \\
C Organic $(\%)$ & $2.21 \pm 0.30$ & $4.16 \pm 0.99$ & $1.51 \pm 0.07$ \\
N Total $(\%)$ & $0.04 \pm 0.00$ & $0.17 \pm 0.04$ & $0.10 \pm 0.01$ \\
C/N Ratio & $55.13 \pm 7.60$ & $25.50 \pm 0.71$ & $16.00 \pm 0.00$ \\
Sand $(\%)$ & $8.84 \pm 0.52$ & $88.00 \pm 9.9$ & $22.00 \pm 2.83$ \\
Silt $(\%)$ & $91.15 \pm 0.51$ & $2.50 \pm 2.21$ & $34.50 \pm 3.54$ \\
Clay (\%) & $0.02 \pm 0.00$ & $9.50 \pm 7.78$ & $43.00 \pm 1.41$ \\
\hline
\end{tabular}

Note: *climatic condition (BMKG 2019), **soil condition (soil analysis)

\section{Data analysis}

Vegetation composition and structure

The composition of plant species was analyzed using an Important Value Index (IVI) (Curtis and McIntosh 1950). IVI was calculated as the sum of relative density and relative frequency. Whereas, relative density and relative frequency were calculated using equation:

Relative Density $=\frac{\text { Number of individuals of a species }}{\text { Total number of individuals of all species }} \times 100 \%$

Relative Frequency $=\frac{\text { Frequency value of a species }}{\text { Total frequency value of all species }} \times 100 \%$

The level of similarity of the Imperata grassland at the three research sites was analyzed using the Sorensen similarity index (Magurran 2004).

$$
S I=\frac{2 w}{a+b}
$$

Where: SI: Similarity index, w: number of species that appear in the communities a and $b$, a: number of species in community $a, b$ : number of species found in community $b$.

Richness, diversity, evenness, and dominance of plant species

The species richness in each community was analyzed using Menhinick richness index $\left(D_{m n}\right)$, the plant species diversity was analyzed using the Shannon diversity index $\left(\mathrm{H}^{\prime}\right)$, the species evenness in each community was analyzed using the Pielou evenness index $\left(\mathrm{J}^{\prime}\right)$, while the species dominance in each community was analyzed using the Simpson dominance index (D) (Magurran 2004). The three indices are formulated as follows:

$$
\begin{aligned}
& D_{m n}=\frac{S}{\sqrt{N}} \\
& H^{\prime}=-\sum_{i=1}^{n}\left[\left(\frac{n_{i}}{N}\right) \ln \left(\frac{n_{i}}{N}\right)\right]
\end{aligned}
$$

$$
\begin{aligned}
& \mathrm{J}^{\prime}=\frac{H^{y}}{\ln (S)} \\
& D=\sum_{i=1}^{n}\left(\frac{n_{i}}{N}\right)^{2}
\end{aligned}
$$

Where; $\mathrm{D}_{\mathrm{mn}}$ : Menhinick richness index, $\mathrm{S}$ : Number of all species, N: Total number of individuals of all species, H': Shannon diversity index, ni: Number of individuals of each species, J': Pielou evenness Index, and D: Simpson dominance index.

\section{Comparison between variables and correlation Imperata} cylindrica abundance between other variables

Comparative analysis of the average value of the following variables across the three sites was conducted using One Way Anova: the abundance of I. cylindrica, number of species other than I. cylindrica, the abundance of species other than I. cylindrica, richness, diversity, evenness and dominance. While the relationship between the abundance of I. cylindrica with other variables using Pearson Correlation analysis. The statistical analysis is using Paleontological Statistics (PAST) version 4.0.

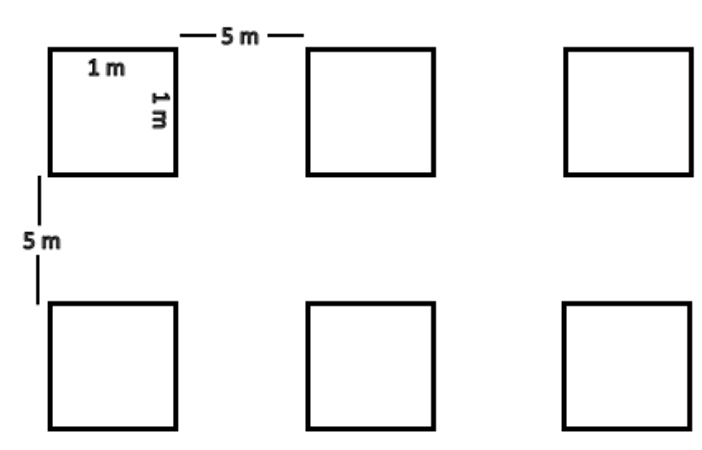

Figure 2. Research plot design 


\section{RESULTS AND DISCUSSION}

\section{Vegetation composition and structure}

The total number of plant species occurred in the Imperata grasslands at the research sites in Bogor, Katingan, and Kupang was 81 species belonging to 68 genera and 30 families with the number of plant species varied across the three sites. Imperata grassland in Bogor had the highest species number (53 species) belonging to 45 genera and 19 families, followed by Imperata grasslands in Kupang with 26 species, included in 24 genera and 13 families, then Imperata grassland in Katingan which consisted of 17 species belonging to 16 genera and 13 families.

The three research sites were dominated by species from the family of Compositae (16.05\%), then followed by Poaceae $(14.91 \%)$, Leguminosae $(11.11 \%)$, Cyperaceae (7.41\%), Rubiaceae (4.94\%), Commelinaceae (4.94\%), Oxalidaceae (3.70\%), Phyllanthaceae (3.70\%), and Acanthaceae $(3.70 \%)$ (Figure 3). Compositae had the highest number of species in Imperata grassland in Bogor (12 species or $22.64 \%$ of the total species). The dominant family in Imperata grassland in Katingan was Cyperaceae (3 species or $17.65 \%$ of the total species), whereas Imperata grassland in Kupang was dominated by Poaceae (8 species or $30.77 \%$ of the number of species).

In comparison, a grassland in Brazil was generally dominated by plant species from the family Poaceae, Compositae (Asteraceae), Cyperaceae, and Leguminosae (Pinto et al. 2013). The dominance of Compositae, Poaceae, and Leguminosae in Imperata grassland was also found in India (Astapati and Das 2012). The Compositae grows generally on open area in which seed dispersal is generally aided by wind and it produces secondary metabolics, so that they can adapt and compete in these habitats (Döring 2019).
Poaceae had the highest importance value index (IVI) in the three research sites with $66.03 \%$ (Bogor), $113.15 \%$ (Katingan), and $127.99 \%$ (Kupang), followed by Compositae and Leguminosae (Figure 4). Imperata cylindrica had the highest abundance, were found in all observation plots, and was the most dominant species with the highest IVI. In the Bogor site, the species with the highest IVI was I. cylindrica (43.71\%), then followed by Ageratum conyzoides (12.21\%), and Phyllanthus niruri $(11.82 \%)$ (Table 2). In Katingan site, species with the highest IVI was I. cylindrica (110.48\%), followed by Scleria ciliaris (20.63\%), Cyanthillium cinereum (17.05\%), and Vitex pinnata (12.58\%) (Table 3), whereas in Kupang, the highest IVI was I. cylindrica (110.04\%), followed by Tridax procumbens $(12.24 \%)$ (Table 4$)$.

The dominant species other than I. cylindrica at the three research sites in this study are different from the Indian Imperata grassland. In India, besides I. cylindrica, the dominant species are Borreria pusilla, Setaria glauca, Digitaria longiflora, and Chromolaena odorata (Astapati and Das 2012). In the succession stage of Imperata grasslands in East Kalimantan, the dominant species other than I. cylindrica are Nephrolepis biserrata, Bridelia glauca, Fordia splendidissima, and Scleria terrestris (Yassir and Arbainsyah 2014). Whereas on a succession vegetation 6 months after a fire in West Java, the dominant species other than I. cylindrica are Gonostegia hirta, Plectranthus teysmannii, Pteridium aquilinum, Eragrostis nigra, and Pteridium aquilinum (Sulistyawati and Fitriana 2017). The success of a species to dominate an area is influenced by its adaptability to physical environmental factors, such as air temperature, light and humidity, biotic factors such as interactions among species, competition, and parasitism, and chemical factors such as availability of water, oxygen, $\mathrm{pH}$, and nutrients in the soil (Krebs 1994).

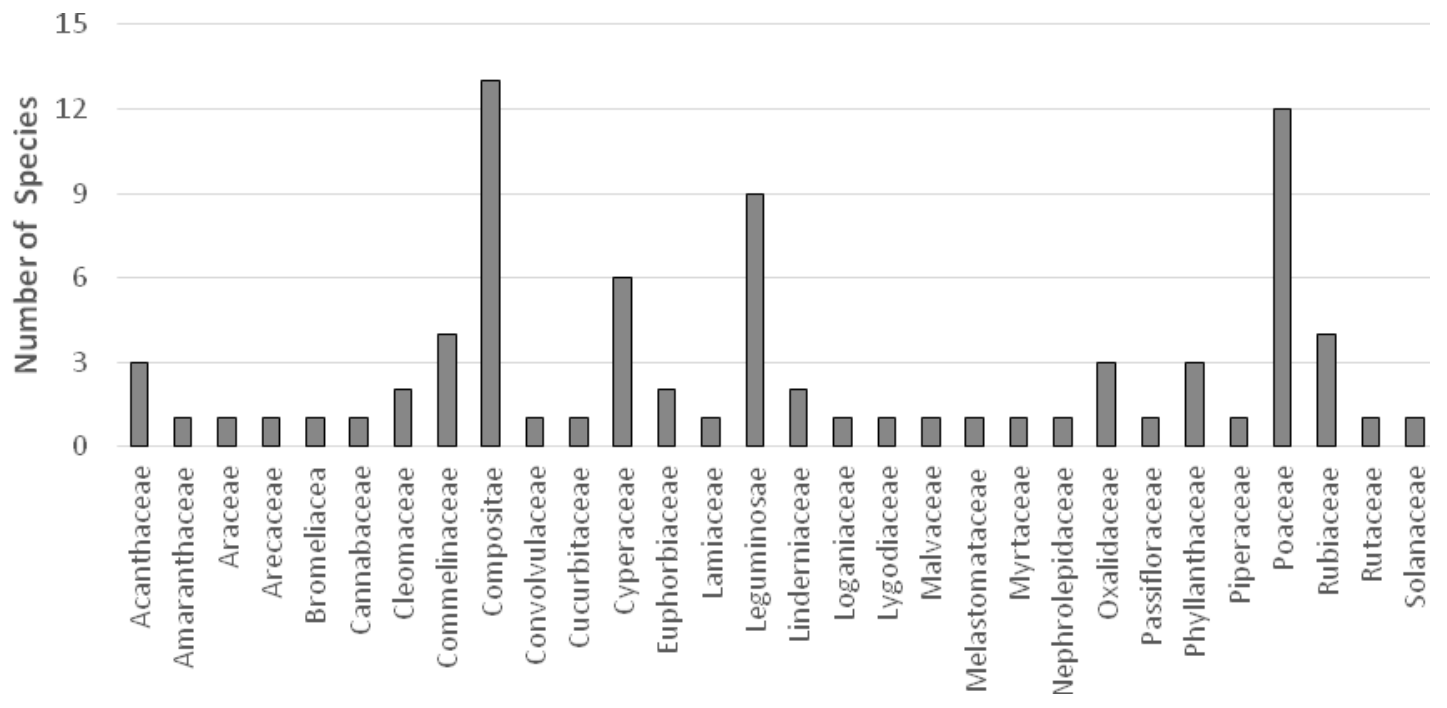

Figure 3. Number of plant species in each family found at the three research sites 
Table 2. The importance value index (IVI) of each plant species in the Bogor site, Indonesia

\begin{tabular}{|c|c|c|c|c|c|c|c|}
\hline Species & Family & Habitus & $\begin{array}{c}\text { Invasive/ } \\
\text { non-invasive }\end{array}$ & $\begin{array}{c}\text { Native/ } \\
\text { non-native }\end{array}$ & $\begin{array}{l}\text { RD } \\
(\%)\end{array}$ & $\begin{array}{r}\mathbf{R F} \\
(\%)\end{array}$ & $\begin{array}{l}\text { IVI } \\
(\%)\end{array}$ \\
\hline $\begin{array}{l}\text { Imperata cylindrica (L.) P.Beauv. } \\
\text {. }\end{array}$ & Poaceae & Herb & Invasive & Non-native & 40.48 & 6.83 & 47.31 \\
\hline Ageratum conyzoides (L.) L. & Compositae & Herb & Invasive & Non-native & 6.40 & 5.80 & 12.21 \\
\hline Phyllanthus niruri L. & Phyllanthaceae & Herb & Non-invasive & Non-native & 7.38 & 4.44 & 11.82 \\
\hline Panicum maximum Jacq. & Poaceae & Herb & Non-invasive & Non-native & 4.98 & 4.10 & 9.08 \\
\hline Urochloa glumaris (Trin.) Veldkamp & Poaceae & Herb & Non-invasive & Native & 5.70 & 3.07 & 8.77 \\
\hline Spermacoce alata Aubl. & Rubiaceae & Herb & Non-invasive & Non-native & 3.15 & 5.12 & 8.27 \\
\hline Arachis sp. & Leguminosae & Shrub & ni & ni & 3.75 & 3.41 & 7.16 \\
\hline Mimosa pudica $\mathrm{L}$. & Leguminosae & Shrub & Non-invasive & Non-native & 2.63 & 4.44 & 7.07 \\
\hline Centrosema sp. & Leguminosae & Liana & ni & ni & 2.13 & 4.44 & 6.57 \\
\hline Emilia sonchifolia (L.) DC. ex DC. & Compositae & Herb & Non-invasive & Native & 0.91 & 4.78 & 5.69 \\
\hline Oldenlandia corymbosa $\mathrm{L}$. & Rubiaceae & Herb & Non-invasive & Native & 1.52 & 4.10 & 5.62 \\
\hline Tridax procumbens (L.) L. & Compositae & Herb & Non-invasive & Non-native & 2.50 & 3.07 & 5.57 \\
\hline Oxalis barrelieri L. & Oxalidaceae & Herb & Non-invasive & Non-native & 0.57 & 4.10 & 4.66 \\
\hline Pachystachys sp. & Acanthaceae & Shrub & ni & ni & 0.84 & 3.41 & 4.26 \\
\hline Murdannia nudiflora (L.) Brenan & Commelinaceae & Herb & Non-invasive & Native & 1.56 & 2.39 & 3.94 \\
\hline Euphorbia hirta L. & Euphorbiaceae & Herb & Non-invasive & Non-native & 0.14 & 3.41 & 3.56 \\
\hline Asystasia sp. & Acanthaceae & Herb & ni & ni & 1.17 & 1.71 & 2.88 \\
\hline Rhynchospora colorata (L.) H.Pfeiff. & Cyperaceae & Herb & Non-invasive & Non-native & 0.48 & 2.39 & 2.87 \\
\hline Axonopus compressus (Sw.) P.Beauv. & Poaceae & Herb & Non-invasive & Non-native & 1.07 & 1.71 & 2.77 \\
\hline Wedelia sp. & Compositae & Herb & ni & ni & 1.23 & 1.37 & 2.59 \\
\hline Lindernia crustacea (L.) F.Muell. & Linderniaceae & Herb & Non-invasive & Non-native & 1.35 & 1.02 & 2.38 \\
\hline $\begin{array}{l}\text { Chromolaena odorata (L.) R.M.King \& } \\
\text { H.Rob. }\end{array}$ & Compositae & Shrub & Invasive & Non-native & 0.60 & 1.71 & 2.31 \\
\hline Synedrella nodiflora (L.) Gaertn. & Compositae & Herb & Non-invasive & Non-native & 0.57 & 1.71 & 2.28 \\
\hline Asystasia gangetica (L.) T.Anderson & Acanthaceae & Herb & Invasive & Non-native & 1.34 & 0.68 & 2.02 \\
\hline Cynodon dactylon (L.) Pers. & Poaceae & Herb & Invasive & Native & 0.97 & 1.02 & 1.99 \\
\hline Digitaria fuscescens (J.Presl) Henrard & Poaceae & Herb & Non-invasive & Native & 1.47 & 0.34 & 1.82 \\
\hline Cleome rutidosperma DC. & Cleomaceae & Herb & Non-invasive & Non-native & 0.08 & 1.71 & 1.79 \\
\hline Torenia violacea (Azaola ex Blanco) Pennell & Linderniaceae & Herb & Non-invasive & Native & 0.30 & 1.37 & 1.67 \\
\hline Cyperus rotundus $\mathrm{L}$. & Cyperaceae & Herb & Invasive & Native & 0.58 & 1.02 & 1.60 \\
\hline Ipomoea triloba $\mathrm{L}$. & Convolvulaceae & Liana & Non-invasive & Non-native & 0.23 & 1.37 & 1.60 \\
\hline Spilanthes iabadicensis A.H.Moore & Compositae & Herb & Non-invasive & Non-native & 0.50 & 1.02 & 1.52 \\
\hline Spermacoce laevis Lam. & Rubiaceae & Herb & Non-invasive & Non-native & 0.14 & 1.37 & 1.51 \\
\hline Borreria sp. & Rubiaceae & Herb & ni & $\mathrm{ni}$ & 0.14 & 1.37 & 1.51 \\
\hline Aeschynomene americana $\mathrm{L}$. & Leguminosae & Shrub & Non-invasive & Non-native & 0.73 & 0.68 & 1.41 \\
\hline Fimbristylis quinquangularis (Vahl) Kunth & Cyperaceae & Herb & Non-invasive & Native & 0.74 & 0.34 & 1.08 \\
\hline Sida rhombifolia $\mathrm{L}$. & Malvaceae & Herb & Non-invasive & Non-native & 0.04 & 1.02 & 1.06 \\
\hline Murdannia spirata (L.) G.Brückn. & Commelinaceae & Herb & Non-invasive & Native & 0.33 & 0.68 & 1.01 \\
\hline Phyllanthus urinaria $\mathrm{L}$. & Phyllanthaceae & Herb & Non-invasive & Native & 0.29 & 0.68 & 0.98 \\
\hline Commelina sp. & Commelinaceae & Herb & ni & ni & 0.20 & 0.68 & 0.89 \\
\hline Oxalis dumetorum Barnéoud & Oxalidaceae & Herb & Non-invasive & Non-native & 0.09 & 0.68 & 0.77 \\
\hline Mikania cordata (Burm.f.) B.L.Rob. & Compositae & Herb & Non-invasive & Native & 0.04 & 0.68 & 0.72 \\
\hline Cyanthillium cinereum (L.) H.Rob. & Compositae & Herb & Non-invasive & Native & 0.02 & 0.68 & 0.70 \\
\hline Syzygium polyanthum (Wight) Walp. & Myrtaceae & Herb & Non-invasive & Native & 0.02 & 0.68 & 0.70 \\
\hline Commelina diffusa Burm.f. & Commelinaceae & Herb & Non-invasive & Native & 0.21 & 0.34 & 0.55 \\
\hline Oxalis corymbosa (DC.) Lourteig & Oxalidaceae & Herb & Non-invasive & Non-native & 0.13 & 0.34 & 0.47 \\
\hline Mimosa invisa Colla & Leguminosae & Herb & Invasive & Non-native & 0.09 & 0.34 & 0.43 \\
\hline Blumea lacera (Burm.f.) DC. & Compositae & Herb & Non-invasive & Native & 0.05 & 0,34 & 0.39 \\
\hline Clausena excavata Burm.f. & Rutaceae & Shrub & Non-invasive & Native & 0.04 & 0.34 & 0.38 \\
\hline Erigeron sumatrensis Retz. & Compositae & Herb & Non-invasive & Non-native & 0.02 & 0.34 & 0.36 \\
\hline Spigelia anthelmia $\mathrm{L}$. & Loganiaceae & Herb & Non-invasive & Non-native & 0.02 & 0.34 & 0.36 \\
\hline Celosia argentea $\mathrm{L}$. & Amaranthaceae & Tree & Non-invasive & Non-native & 0.01 & 0.34 & 0.35 \\
\hline Porophyllum ruderale (Jacq.) Cass. & Compositae & Herb & Non-invasive & Non Native & 0.01 & 0.34 & 0.35 \\
\hline Peperomia pellucida (L.) Kunth & Piperaceae & Herb & Non-invasive & Non-native & 0.01 & 0.34 & 0.35 \\
\hline
\end{tabular}
Note: ni: not identified, RD: Relative Density, RF: Relative Frequency, IVI: Important Value Index

The only species found at the three research sites was $I$. cylindrica, while the other plant species found at each study site were different. The similarity of the three Imperata grasslands analyzed using Sorensen similarity index varied from 0.05 to 0.20 . It means that the vegetation communities among the three research sites are not similar and show different plant species. The Sorensen similarity index value of the Imperata grasslands in Bogor and Katingan was 0.14 in which there were five species of plants found concurrently in the two locations, namely $I$. 
cylindrica, Cyanthillium cinereum, Spermacoce alata, Urochloa glumaris, and Oldenlandia corymbosa. The similarity of the Imperata grasslands in Bogor and Kupang based on the Sorensen similarity index value was 0.20 in which eight similar plant species were found, namely $I$. cylindrica, Cynodon dactylon, Cyperus rotundus, Digitaria fuscescens, Euphorbia hirta, Ipomoea triloba, Spigelia anthelmia, and Tridax procumbens. Whereas Imperata grassland in Katingan and Bogor have a Sorensen similarity index value of 0.05 and only one plant species was concurrently found, namely I. cylindrica. The differences in species composition occurred in the three Imperata grasslands are likely due to differences in climatic and soil conditions (Table 1).

Table 3. The importance value index (IVI) of each plant species in the Katingan site, Indonesia

\begin{tabular}{|c|c|c|c|c|c|c|c|}
\hline Species & Family & Habitus & $\begin{array}{c}\text { Invasive/ } \\
\text { non invasive }\end{array}$ & $\begin{array}{c}\text { Native/ } \\
\text { non-native }\end{array}$ & $\begin{array}{l}\text { RD } \\
(\%)\end{array}$ & $\begin{array}{r}\text { RF } \\
(\%)\end{array}$ & $\begin{array}{l}\text { IVI } \\
(\%)\end{array}$ \\
\hline Imperata cylindrica (L.) P.Beauv. & Poaceae & Herb & Invasive & Non-native & 76.58 & 33.90 & 110.48 \\
\hline Scleria ciliaris Nees & Cyperaceae & Herb & Non-invasive & Native & 3.68 & 16.95 & 20.63 \\
\hline Cyanthillium cinereum (L.) H.Rob. & Compositae & Herb & Non-invasive & Non-native & 11.96 & 5.08 & 17.05 \\
\hline Vitex pinnata $\mathrm{L}$. & Lamiaceae & Tree & Non-invasive & Native & 0.72 & 11.86 & 12.58 \\
\hline Trema orientalis (L.) Blume & Cannabaceae & Tree & Non-invasive & Non-native & 0.61 & 5.08 & 5.70 \\
\hline Scleria triglomerata Michx. & Cyperaceae & Herb & Non-invasive & Non-native & 0.31 & 3.39 & 3.70 \\
\hline Spermacoce alata Aubl. & Rubiaceae & Herb & Non-invasive & Non-native & 1.94 & 1.69 & 3.64 \\
\hline Ananas comosus (L.) Merr. & Bromeliacea & Herb & Non-invasive & Non-native & 0.20 & 3.39 & 3.59 \\
\hline Breynia racemosa (Blume) Müll.Arg. & Phyllanthaceae & Tree & Non-invasive & Native & 0.20 & 3.39 & 3.59 \\
\hline Urochloa glumaris (Trin.) Veldkamp & Poaceae & Herb & Non-invasive & Native & 0.20 & 3.39 & 3.59 \\
\hline Bulbostylis pseudoperennis Goetgh. & Cyperaceae & Herb & Non-invasive & Non-native & 0.92 & 1.69 & 2.62 \\
\hline Nephrolepis biserrata (Sw.) Schott & Nephrolepidaceae & Fern & Non-invasive & Native & 0.92 & 1.69 & 2.62 \\
\hline Melastoma malabathricum $\mathrm{L}$. & Melastomataceae & Shrub & Non-invasive & Non-native & 0.72 & 1.69 & 2.41 \\
\hline Acacia mangium Willd. & Leguminosae & Tree & Invasive & Non-native & 0.41 & 1.69 & 2.10 \\
\hline Oldenlandia corymbosa $\mathrm{L}$. & Rubiaceae & Herb & Non-invasive & Native & 0.41 & 1.69 & 2.10 \\
\hline Lygodium microphyllum (Cav.) R. Br. & Lygodiaceae & Fern & Invasive & Native & 0.10 & 1.69 & 1.80 \\
\hline Passiflora foetida $\mathrm{L}$. & Passifloraceae & Liana & Invasive & Non-native & 0.10 & 1.69 & 1.80 \\
\hline
\end{tabular}

Note: RD: Relative Density, RF: Relative Frequency, IVI: Important Value Index

Table 4. The importance value index (IVI) of each plant species in the Kupang site, Indonesia

\begin{tabular}{|c|c|c|c|c|c|c|c|}
\hline Species & Family & Habitus & $\begin{array}{c}\text { Invasive/ } \\
\text { non invasive }\end{array}$ & $\begin{array}{c}\text { Native/ } \\
\text { non-native }\end{array}$ & $\begin{array}{l}\text { RD } \\
(\%)\end{array}$ & $\begin{array}{r}\text { RF } \\
(\%) \\
\end{array}$ & $\begin{array}{l}\text { IVI } \\
(\%) \\
\end{array}$ \\
\hline Imperata cylindrica (L.) P.Beauv. & Poaceae & Herb & Invasive & Non-native & 84.70 & 25.33 & 110.04 \\
\hline Tridax procumbens (L.) L. & Compositae & Herb & Non-invasive & Non-native & 1.57 & 10.67 & 12.24 \\
\hline Synedrella nodiflora (L.) Gaertn. & Compositae & Herb & Non-invasive & Non-native & 0.41 & 9.33 & 9.74 \\
\hline Flemingia congesta W.T.Aiton & Leguminosae & Shrub & Non-invasive & Native & 1.03 & 5.33 & 6.36 \\
\hline Cynodon dactylon (L.) Pers. & Poaceae & Herb & Invasive & Native & 3.15 & 2.67 & 5.81 \\
\hline Paspalum scrobiculatum L. & Poaceae & Herb & Invasive & Native & 4.31 & 1.33 & 5.64 \\
\hline Mucuna pruriens (L.) DC. & Leguminosae & Liana & Non-invasive & Non-native & 0.25 & 5.33 & 5.58 \\
\hline Corypha utan Lam. & Arecaceae & Tree & Non-invasive & Native & 0.09 & 5.33 & 5.42 \\
\hline Passiflora foetida $\mathrm{L}$. & Passifloraceae & Liana & Invasive & Non-native & 0.09 & 4.00 & 4.09 \\
\hline Sacciolepis myosuroides (R.Br.) A.Camus & Poaceae & Herb & Non-invasive & Native & 2.19 & 1.33 & 3.52 \\
\hline Paspalum conjugatum P.J.Bergius & Poaceae & Herb & Non-invasive & Non-native & 0.43 & 2.67 & 3.10 \\
\hline Euphorbia hypericifolia $\mathrm{L}$. & Euphorbiaceae & Herb & Non-invasive & Non-native & 0.32 & 2.67 & 2.99 \\
\hline Digitaria sp. & Poaceae & Herb & ni & ni & 0.27 & 2.67 & 2.94 \\
\hline Brachiaria mutica (Forssk.) Stapf & Poaceae & Herb & Non-invasive & Non-native & 0.11 & 2.67 & 2.78 \\
\hline Cucumis sativus $\mathrm{L}$. & Cucurbitaceae & Liana & Non-invasive & Non-native & 0.09 & 2.67 & 2.76 \\
\hline Euphorbia hirta L. & Euphorbiaceae & Herb & Non-invasive & Non-native & 0.07 & 2.67 & 2.74 \\
\hline Oryza rufipogon Griff. & Poaceae & Herb & Non-invasive & Non-native & 0.62 & 1.33 & 1.95 \\
\hline Cyperus rotundus $\mathrm{L}$. & Cyperaceae & Herb & Invasive & Native & 0.07 & 1.33 & 1.40 \\
\hline Sonchus arvensis L. & Compositae & Herb & Non-invasive & Non-native & 0.07 & 1.33 & 1.40 \\
\hline Amorphophallus sp. & Araceae & Herb & Non-invasive & Native & 0.02 & 1.33 & 1.36 \\
\hline Cleome viscosa $\mathrm{L}$. & Cleomaceae & Herb & Non-invasive & Native & 0.02 & 1.33 & 1.36 \\
\hline Chromolaena odorata (L.) R.M.King \& H.Rob. & Compositae & Shrub & Invasive & Non-native & 0.02 & 1.33 & 1.36 \\
\hline Ipomoea triloba $\mathrm{L}$. & Convolvulaceae & Liana & Non-invasive & Non-native & 0.02 & 1.33 & 1.36 \\
\hline Vigna umbellata (Thunb.) Ohwi \& H.Ohashi & Leguminosae & Liana & Non-invasive & Native & 0.02 & 1.33 & 1.36 \\
\hline Physalis angulata $\mathrm{L}$. & Solanaceae & Herb & Non-invasive & Non-native & 0.02 & 1.33 & 1.36 \\
\hline Spigelia anthelmia $\mathrm{L}$. & Loganiaceae & Herb & Non-invasive & Non-native & 0.02 & 1.33 & 1.36 \\
\hline
\end{tabular}

Note: ni: not identified, RD: Relative Density, RF: Relative Frequency, IVI: Important Value Index 


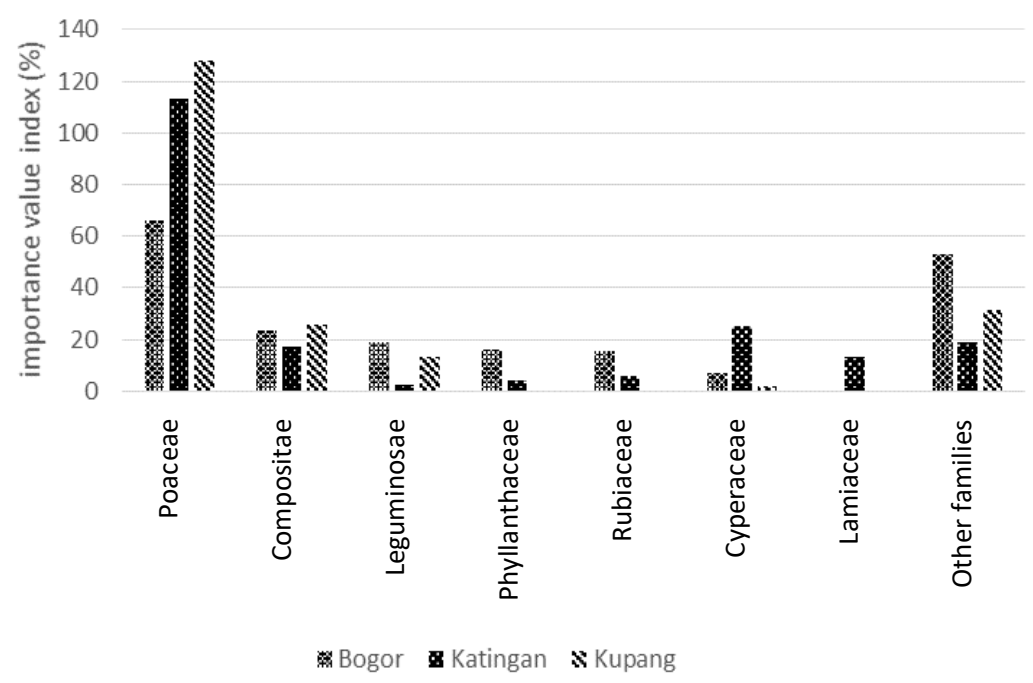

Figure 4. The importance value index (IVI) of the dominant families in three research sites

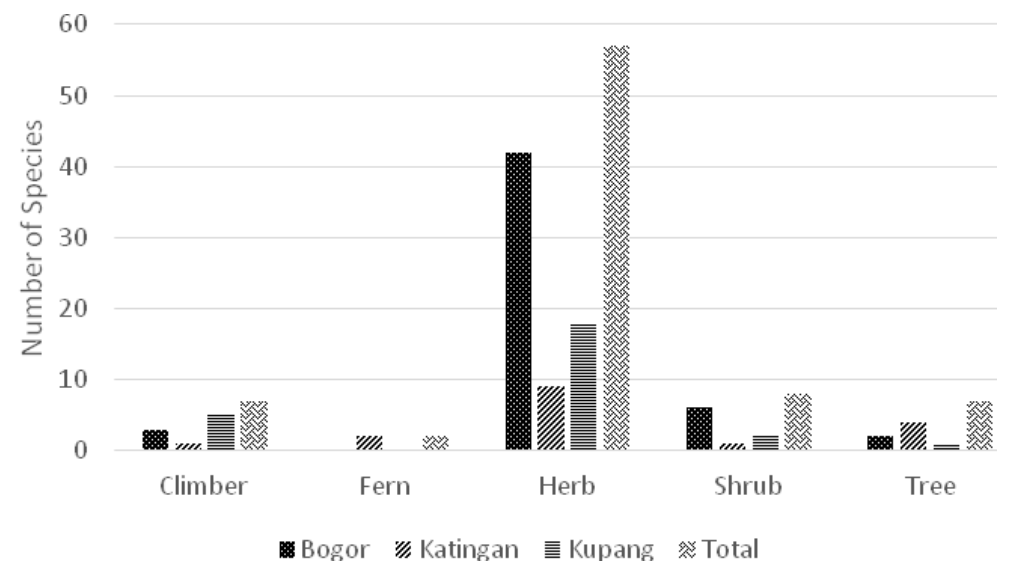

Figure 5. The habitus of plants found in the three Imperata cylindrica grasslands

Based on plant habitus, it is revealed that the three research sites were dominated by herbs species $(70.37 \%)$, followed by shrubs $(9.88 \%)$, and the remainder were trees, lianas, and ferns (Figure 5). Tree species found in the three research sites included Acacia mangium, Breynia racemosa, Celosia argentea, Corypha utan, Syzygium polyanthum, Trema orientalis, and Vitex pinnata. The species of lianas found were the members of Leguminosae, Cucurbitaceae, Convolvulaceae, and Passifloraceae. The fern species found were Nephrolepis biserrata and Lygodium microphyllum.

Across the three research sites, understorey shrubs, herbs, and ferns were found. However, in Katingan, Melastoma malabathricum (shrub), Vitex pinnata and Acacia mangium (tree) were found in a high number of individuals. The presence of $M$. malabathricum and $V$. pinnata is an indicator of the succession process from Imperata grassland to secondary forest, where both species become the dominant species (Yassir and Arbainsyah 2014). Acacia mangium is a fast-growing tree and continuously produces seeds in large quantities, so that the species can compete strongly with other species in the Imperata grasslands (Richardson and Rejmánek 2011; Aguiar et al. 2014). In the Imperata grassland in Kupang, Corypha utan, a native plant species were found.

Based on the Global Invasive Species Database (http://www.iucngisd.org/gisd 2019), at least 11 invasive plant species were found in the three Imperata grasslands. Seven species were found in the Bogor site, four species in Katingan, and six species in Kupang. The invasive plants' species found were mostly herbs, namely I. cylindrica, Ageratum conyzoides, Asystasia gangetica, Cynodon dactylon, Cyperus rotundus, Mimosa invisa, and Paspalum scrobiculatum. The other invasive plant species were shrub (i.e. Chromolaena odorata), tree (i.e. Acacia mangium), liana (i.e. Passiflora foetida), and fern (i.e. Lygodium microphyllum). Of the 11 invasive plant species, only $I$. cylindrica and Ageratum conyzoides were the most dominant species in the Imperata grasslands. 
Imperata cylindrica was the dominant species in the three research sites, however, several species were able to compete with this noxious weed, i.e. Ageratum conyzoides, Phyllanthus niruri, Scleria ciliaris, Cyanthillium cinereum, Vitex pinnata, and Tridax procumbens. A. conyzoides is a herb species that can adapt to various environmental conditions, has a high reproduction and excellent seed dispersal by wind and livestock, and also has allelopathic substances that can inhibit the germination and growth of other undergrowth species (Isda et al. 2013; Wardani et al. 2018). $P$. niruri is known to have allelopathic substances in the roots, leaves, and stems (Mishra 2017). S. ciliaris can grow in various environmental conditions and the seeds can germinate well, so that this plant often becomes dominant weed and is difficult to control (Wahyuni et al. 2015). V. pinnata is a fast-growing tree in an open area and is effective in spreading seeds (Hashim and Hughes 2010). T. procumbent has strong allelopathic activity and can inhibit the growth of other plant species (Andriana et al. 2018).

Plant species that can compete with I. cylindrica (i.e. Ageratum conyzoides, Phyllanthus niruri, Scleria ciliaris, Cyanthillium cinereum, Vitex pinnata, and Tridax procumbens) have some characteristics, such as high reproductive ability, adaptive to various environmental conditions, possessing allelopathy and can carry out generative reproduction through seeds and vegetative through high rhizomes. Imperata is capable of producing c. 3,000 seeds per individual and can be regenerated at a radius of 15 to $100 \mathrm{~m}$ by wind (Dozier et al. 1998; MacDonald 2004). Reproduction through rhizomes is the main way in the spread of Imperata, and the sprouting shoots at each node and the sharp edges of the rhizome can cause physical damage to the roots of the surrounding plants. Imperata rhizomes can withstand fire, soil disturbance, and can penetrate the soil as deep as $1.2 \mathrm{~m}$ (Dozier et al. 1998).

\section{Richness, diversity, evenness, and dominance of plant species}

Plant diversity in Imperata grasslands at plot area of 1 $\mathrm{m}^{2}$ in the three research sites tends to vary which can be seen from the value of the richness index, diversity index, evenness index, and dominance index (Table 5). The results of statistical analysis using the One Way ANOVA show very significant differences among the three research sites in term of richness $\left(\mathrm{F}_{2,57}=20.146, \mathrm{P}=0.00\right)$, diversity $\left(F_{2,57}=104.668, P=0.00\right)$, evenness $\left(F_{2,57}=23.941, P=\right.$ $0.00)$, and dominance $\left(F_{2,57}=64.900, P=0.00\right)$. Species richness in Imperata grasslands at the three research site has a Menhinick richness index $\left(\mathrm{D}_{\mathrm{mn}}\right)$ value of $0.28-0.67$ and can be categorized as low richness. Imperata grassland in Bogor has the highest value of species richness with an average Menhinick richness index value of 0.67 and found an average of 14.65 species in each plot.

Using the Shannon index value $\left(\mathrm{H}^{\prime}\right)$, the level of species diversity can be categorized into three, i.e. low $\left(0<\mathrm{H}^{\prime}<1\right)$, moderate $\left(1 \leq \mathrm{H}^{\prime} \leq 3\right)$, and high $\left(\mathrm{H}^{\prime}>3\right)$ (Fitrian et al. 2017). Plant diversity in Imperata grasslands at the three research sites has Shannon diversity index value of 0.37-1.80 and can be categorized as low to moderate diversity. Imperata grassland in Bogor is the most diverse community with an average Shannon diversity index value of 1.80 , while Kupang has the lowest diversity with a Shannon diversity index value of 0.37 .

Pielou evenness index $\left(\mathrm{J}^{\prime}\right)$ can be categorized into three: i.e. low $\left(\mathrm{J}^{\prime}<0.4\right)$, moderate $\left(0.4 \leq \mathrm{J}^{\prime}<0.6\right)$, and high $\left(\mathrm{J}^{\prime} \geq 0.6\right)$ (Fitrian et al. 2017). The evenness of plant communities in Imperata grasslands in the three research sites has an average value of $0.24-0.68$ and this can be categorized as low to high. In terms of species evenness, Imperata grassland in Bogor has the most uniform species abundance with an average Pielou evenness index of 0.68 , while Kupang Imperata grassland has low species evenness with an average value of 0.24 .

Table 5. The richness, diversity, evenness and dominance index of plant species in the three research sites

\begin{tabular}{lccccc}
\hline \multicolumn{1}{c}{ Variables } & Bogor & Katingan & Kupang & F & P \\
\hline Menhinick richness index & $0.67 \pm 0.11$ & $0.47 \pm 0.28$ & $0.28 \pm 0.15$ & $20.146^{* *}$ & 0.000 \\
Shannon diversity index & $1.80 \pm 0.39$ & $0.43 \pm 0.40$ & $0.37 \pm 0.27$ & $104.668^{* * *}$ & 0.000 \\
Pielou evenness index & $0.68 \pm 0.13$ & $0.34 \pm 0.30$ & $0.24 \pm 0.17$ & $23.941^{* *}$ & 0.000 \\
Simpson dominance index & $0.27 \pm 0.14$ & $0.77 \pm 0.22$ & $0.84 \pm 0.14$ & $64.900^{* *}$ & 0.000 \\
\hline
\end{tabular}

Note: Value $=$ Average \pm Standard Deviation, ${ }^{* *}$ significant in $1 \%$ level

Table 6. Imperata cylindrica abundance, number of species other than I. cylindrica, and species abundance other than $I$. cylindrica in three research sites

\begin{tabular}{|c|c|c|c|c|c|}
\hline Variables & Bogor & Katingan & Kupang & $\mathbf{F}$ & $\mathbf{P}$ \\
\hline I. cylindrica abundance & $199.15 \pm 133.15$ & $37.45 \pm 21.23$ & $185.80 \pm 121.69$ & $14.652^{* *}$ & 0.000 \\
\hline Number of species other than I. cylindrica & $13.65 \pm 2.98$ & $1.90 \pm 1.74$ & $2.75 \pm 1.97$ & $163.089^{* *}$ & 0.000 \\
\hline Abundance of species other than I. cylindrica & $292.80 \pm 115.63$ & $14.45 \pm 31.02$ & $33.55 \pm 51.61$ & $85.352^{* *}$ & 0.000 \\
\hline
\end{tabular}

Note: Value $=$ Average \pm Standard Deviation, ${ }^{* *}$ significant in $1 \%$ level 
Table 7. Pearson Correlations between Imperata cylindrica abundance with several other variables at the three research sites

\begin{tabular}{|c|c|c|c|c|c|c|}
\hline \multirow{2}{*}{$\begin{array}{c}\text { Imperata cylindrica abundance } \\
\text { with }\end{array}$} & \multicolumn{2}{|c|}{ Bogor } & \multicolumn{2}{|c|}{ Katingan } & \multicolumn{2}{|c|}{ Kupang } \\
\hline & $\mathbf{R}$ & $\mathbf{P}$ & $\mathbf{r}$ & $\mathbf{P}$ & $\mathbf{r}$ & $\mathbf{P}$ \\
\hline Abundance of species other than I. cylindrica & $-0.400^{*}$ & 0.470 & -0.057 & 0.811 & -0.41 & 0.088 \\
\hline Number of species other than I. cylindrica & 0.020 & 0.934 & -0.247 & 0.293 & 0.001 & 0.998 \\
\hline Menhinick richness index & $-0.463^{*}$ & 0.400 & $-0.606^{* *}$ & 0.005 & $-0.476^{*}$ & 0.034 \\
\hline Shannon diversity index & $-0.777^{* *}$ & 0.000 & $-0.586^{* *}$ & 0.007 & -.0 .387 & 0.092 \\
\hline Pielou evenness index & $-0.860^{* *}$ & 0.000 & $-0.552^{*}$ & 0.012 & -0.407 & 0.075 \\
\hline Simpson dominance index & $0.872^{* *}$ & 0.000 & $0.577^{* *}$ & 0.008 & 0.355 & 0.124 \\
\hline
\end{tabular}

Note: ${ }^{*}$ significant in $5 \%$ level, ${ }^{* *}$ significant in $1 \%$ level

The Simpson dominance index range from 0 to 1 , with high values indicating strong dominance of a species in the community (Odum and Barrett 2004). The Simpson dominance index (D) in the three research sites has a value of 0.27-0.84. Imperata grasslands in Katingan and Kupang have high dominance index values of 0.77 and 0.84 , respectively. Imperata grassland in Bogor has moderate to high species diversity, the distribution of the abundance of each species tends to be uniform, and the Imperata does not dominate the vegetation. The Imperata grasslands in Katingan and Kupang have low species diversity, species abundance is uneven, and Imperata tends to be more dominant.

In comparison, Imperata grasslands in India have an average Shannon diversity index of 0.7-1.38 and an evenness index of 0.46-0.48 (Astapati and Das 2012). The diversity and evenness of Imperata grassland in Bogor has higher value than that of the Imperata grassland in India, but the Katingan and Kupang sites have lower species diversity and evenness. Plant community in timber plantations in South Sumatra dominated by I. cylindrica has a low diversity $\left(\mathrm{H}^{\prime}=0.78-0.83\right)$ (Kunarso and Azwar 2013). Compared to these plantations, the diversity of the Katingan and Kupang grasslands is lower, but it should be noted that Imperata grasslands in Bogor have higher diversity. Imperata grassland in Bogor has higher plant diversity, and this can prevent a wider invasion of $I$. cylindrica at that location. However, this is not the case with the Katingan and Kupang grasslands which have low species diversity, so that the possibility of the location being invaded by weeds will be even higher in the future.

\section{Comparison between variables and correlation} Imperata cylindrica abundance between other variables

Using One Way Anova's statistical analysis, there were significant differences across the three sites in terms of $I$. cylindrica abundance $\left(\mathrm{F}_{2,57}=14.652, \mathrm{P}=0.00\right)$, the number of species other than I. cylindrica $\left(\mathrm{F}_{2,57}=163.089, \mathrm{P}=\right.$ $0.00)$, and the abundance of species other than I. cylindrica $\left(\mathrm{F}_{2,57}=85.352, \mathrm{P}=0.00\right)$ (Table 6). Bogor grassland has the highest abundance of I. cylindrica and number of species other than I. cylindrica compared to the other two research sites.

Based on the Pearson Correlation analysis between the abundance of $I$. cylindrica and the species other than $I$. cylindrica, the abundance of species other than $I$. cylindrica, richness, diversity, evenness and dominance index in the three research sites have varying values. The relationship between Imperata grassland abundance and other plant species abundance in Imperata grassland in Bogor tends to be negative, while the Imperata grassland vegetation in Katingan and Kupang has no significant relationship (Table 7). The abundance of Imperata also negatively affects species richness, species diversity and evenness of species, and has a positive correlation with species dominance in the Imperata grasslands in Bogor and Katingan. Whereas in Kupang, the abundance of $I$. cylindrica only has negatively affects species richness and does not significantly influence other variables.

Correlation between than I. cylindrica abundance and number of species other than I. cylindrica has insignificant correlation. In Katingan has a negative correlation $(\mathrm{r}=$ 0.247) while Bogor and Kupang are positive correlations ( $\mathrm{r}$ $=0.020$ and $r=0.001)$. Based on the analysis, it is revealed that the increasing abundance of I. cylindrica causes a decrease in the abundance of other plant species. The decrease in the abundance of other species causes the reduction in the level of species richness, species diversity and evenness of species, and increases the dominance of $I$. cylindrica in the research sites. The results of Brewer (2008,) showed the invasion of I. cylindrica in longleaf pine (Pinus palustris) communities, Mississippi, United States causes a decrease in the number of native species between 2-4 individuals in plots $0.25 \mathrm{~m}^{2}$ in a period of 3 years, whereas in the next 2 years there was no relative decline in the number of native species. Increase in the abundance of I. cylindrica that dominates the competition, the abundance of species other than I. cylindrica was diminished and this might have resulted in the reduction of species that grew in the community.

In conclusion, I. cylindrica was the dominant species in the Imperata grasslands in Bogor, Katingan, and Kupang, but other species were also found in which some of them were invasive species. The presence of species other than $I$. cylindrica suggests that these species can grow and compete with Imperata. However, efforts to control $I$. cylindrica and the other invasive species populations should not inhibit the growth of other species, so that the succession process of Imperata grasslands into forest vegetation runs well and could even restore the biodiversity. 


\section{ACKNOWLEDGEMENTS}

This research is part of The Science and Technology Research Partnership for Sustainable Development (SATREPS) project entitled "Producing Biomass Energy and Material through Revegetation of Alang-alang (Imperata cylindrica) Fields", a collaboration between Indonesian Institute of Sciences and Kyoto University, Japan. This research was funded by the competitive program of Indonesian Institute of Sciences and the thematic program of Research Center for the Plant Conservation and Botanic Gardens, Bogor, Indonesia in 2016. The authors thank all colleagues who have supported this research.

\section{REFERENCES}

Aguiar A, Barbosa RI, Barbosa JBF, Mourao MJ. 2014 Invasion of Acacia mangium in Amazonian savannas following planting of forestry. Plant Ecol Divers 1 (2): 359-369.

Andriana Y, Xuan TD, Quan NV, Quy TN. 2018. Allelopathic potential of Tridax procumbens $\mathrm{L}$. on radish and identification of allelochemicals. Allelopath J 43 (2): 223-238.

Astapati AD, Das AK. 2012. Analysis of vegetation in an Imperata grassland of Barak valley, Assam. J Environ Biol 33: 855-860.

BMKG - Meteorological, Climatological, and Geophysical Agency. 2019. Climate data. http://www.dataonline.bmkg.go.id. [Indonesian]

Brewer S. 2008. Declines in plant species richness and endemic plant species in longleaf pine savannas invaded by Imperata cylindrica. Biol Invasions 10: 1257-1264.

Central Bureau of Statistics. 2017. Environment Statistics of Indonesia 2017. Central Bureau of Statistics Republic of Indonesia, Jakarta. [Indonesian]

Curtis JT, McIntosh RP. 1950. The interrelations of certain analytic and synthetic phytosociological characters. Ecology 31 (3): 435-455.

Daneshgar P, Jose S. 2009. Role of species identity in plant invasions: experimental test using Imperata cylindrica. Biol Invasions 11: 14311440.

Döring M. 2019. Asteraceae Bercht. \& J.Presl. Wikimedia Foundation.

Dozier H, Gaffney JF, McDonald SK, Johnson ERRL, Shilling DG. 1998 Cogongrass in the United States: history, ecology, impacts, and management. Weed Tech 12: 737-743.

Fitrian T, Kusnadi A, Persilette RN. 2017. Seagrass community structure of Tayando-Tam Island, Southeast Moluccas, Indonesia. Biodiversitas 18 (2): 788-794.

Garrity DP, Soekardi M, van Noordwijk M, De La Cruz R, Pathak PS, Gunasena HPM, Van So N, Huijun G, Majid NM. 1997. The Imperata grasslands of tropical Asia: area, distribution, and typology. Agrofor Syst 36: 3-29.

GISD - Global Invasive Species Database. 2019. Global Invasive Species Database. http://www.iucngisd.org/gisd.

GISD - Global Invasive Species Database. 2020. Species profile: Imperata cylindrica. http://www.iucngisd.org/gisd/species.php.
Hashim NR, Hughes FMR . 2010. The responses of secondary forest tree seedlings to soil enrichment in Peninsular Malaysia: an experimental approach. Trop Ecol 51 (2): 173-182.

Isda MN, Fatonah S, Fitri R. 2013. Potency of babadotan (Ageratum conyzoides L.) weed leaf extract on germination and growth of Paspalum conjugatum Berg. Al-Kauniyah 6 (2): 120-125. [Indonesian]

Krebs CJ. 1994. Ecology: the experimental analysis of distribution and abundance, Fourth Edition. HarperCollins College Publishers, New York.

Kunarso A, Azwar F. 2013. Understorey diversity on several plantation forests stands in Benakat, South Sumatra. J Penelitian Hutan Tanaman 10 (2): 85-98. [Indonesian]

Lippincott CL. 2000. Effects of I. cylindrical (cogongrass) invasions on fire regimes in Florida sandhill. Nat Areas J 20: 140-149.

MacDonald GE. 2004. Cogongrass (Imperata cylindrica) biology, ecology, and management. Crit Rev in Plant Sci 23: 367-380.

Magurran AE. 2004. Measuring Biological Diversity. Blackwell Publishing, Oxford.

Mishra SK. 2017. Allelopathic potential of Phyllanthus niruri Linn. on seed germination and seedling growth of rice (Oryza sativa). Res $\mathbf{J}$ Pharm Phytochem 9 (2): 77-82.

Mitchell RM, Bakker JD, Vincent JB, Davies GM. 2017. Relative importance of abiotic, biotic, and disturbance drivers of plant community structure in the sagebrush steppe. Ecol Appl 27 (3): 756768.

Odum EP, Barrett GW. 2004. Fundamentals of Ecology. 5th ed. Cengage Learning, New York.

Pinto MF, Nabinger C, Boldrini II, Ferreira PMA, Setubal RB, Trevisan R, Fedrigo JK, Carassai IJ. 2013. Floristic and vegetation structure of a grassland plant community on shallow basalt in southern Brazil. Acta Bot Bras 27 (1): 162-179.

Richardson DM, Rejmánek M. 2011. Trees and shrubs as invasive alien species-a global review. Divers Distrib 17: 788-809.

Sulistyawati E, Fitriana S. 2017. Post fire succession in Tegal Panjang Grassland, Mount Papandayan, West Java, Indonesia. Biodiversitas 18 (3): 1226-1233.

USDA - Agricultural Research Service, National Plant Germplasm System. 2020. Germplasm Resources Information Network. https://npgsweb.ars-grin.gov/gringlobal/taxonomydetail.aspx.

Wahyuni I, Sulistijorini, Tjitrosoedirdjo S. 2015. Inventory of invasive plant species at Bukit Duabelas National Park and the Vicinity, Jambi, Sumatra. In: Miftahudin, Juliandi B, Muttaqin M (eds) Proceedings of International Conference on Biosciences (ICoBio). Bogor Agricultural University, Bogor, 5 -7 August 2015. [Indonesian]

Wardani ADK, Darmanti S, Budihastuti R. 2018. Allelochemical effect of Ageratum conyzoides L. leaf extract on Soybean (Glycine max (L.) Merr. cv Grobogan) growth. J Physics: Conf Ser 1025. DOI: 10.1088/1742-6596/1025/1/012044

Yassir I, Arbainsyah. 2014. Diversity of plant communities in secondary succession of Imperata grasslands in Samboja Lestari, East Kalimantan, Indonesia. Indon J For Res 1 (2): 139-149.

Yassir I, Kamp JVD, Buurman P. 2010. Secondary succession after fire in Imperata grasslands of East Kalimantan, Indonesia. Agric Ecosyst Environ 137: 172-182.

Yonekura Y, Ohta S, Kiyono Y, Aksa D, Morisada K, Tanaka N, Kanzaki M. 2009. Changes in soil carbon stock after deforestation and subsequent establishment of "Imperata" grassland in the Asian humid tropics. Plant Soil 329 (1-2): 495-507. 